\title{
The training of neonatologists and the paradigms implied in their relationship with the parents of babies in the Neonatal Intensive Care Unit
}

\author{
A formação do neonatologista e os paradigmas implicados na relação com os pais dos bebês na Unidade \\ de Terapia Intensiva Neonatal
}

La formación del neonatologista y los paradigmas implicados en la relación con los padres y los bebés en la Unidad de Terapia Intensiva Neonatal

Ethel Cukierkorn Battikha1, Maria Teresa de M. Carvalho², Benjamin Israel Kopelman'1

\section{ABSTRACT}

Objective: To analyze and to interpret the psychological repercussions generated by the presence of parents in the Neonatal Intensive Care Unit for residents in Neonatology.

Methods: Study based on the psychoanalytic theory, involving a methodological interface with qualitative surveys in Health Sciences. Twenty resident physicians in Neonatology, from five public institutions of São Paulo state, responded to a single semi-structured interview. Based on several readings of the material, achieving the core of emergent meanings that would be significant to the object of the survey, six categories were elected for analysis and interpretation: parents' staying at the Neonatal Intensive Care Unit and its effects on the neonatologists' professional practice; communication of the diagnosis and what parents should know; impasses between parents and doctors when the diagnosis is being communicated; doctor's identification with parents; communication of the child's death and their participation in the interview.

Results: The interpretation of the categories provided an understanding of the psychic mechanisms mobilized in doctors in their relationships with the children's parents, showing that the residents experience anguish and suffering when they provide medical care and during their training process, and also that they lack psychological support to handle these feelings.
Conclusions: There is a need of intervention in neonatologists training and education, which may favor the elaboration of daily experiences in the Unit, providing a less anguishing and defensive way out for young doctors, especially in their relationship with patients and parents.

Key-words: education, medical; internship and residency; neonatology; psychoanalysis.

\section{RESUMO}

Objetivo: Analisar e interpretar as repercussões psicológicas suscitadas no médico neonatologista em formação devido à entrada e à permanência dos pais na Unidade de Terapia Intensiva Neonatal.

Métodos: Estudo sustentado na teoria psicanalítica, mantendo-se uma interlocução metodológica com a pesquisa qualitativa em saúde. Vinte residentes de Neonatologia, de cinco instituições públicas do estado de São Paulo, participaram de uma entrevista semiestruturada individual. A partir de inúmeras leituras do material, objetivando-se os núcleos de sentido emergentes, significativos para o objeto de pesquisa, elegeram-se seis categorias para análise e interpretação: permanência dos pais na Unidade de Terapia Intensiva Neonatal e sua repercussão na atuação do neonatologista; comunicação do diagnóstico e o que os pais devem saber; impasses entre os médicos e os pais dos bebês na comunica-
Instituição: Escola Paulista de Medicina da Universidade Federal de São Paulo (Unifesp), São Paulo, SP, Brasil

${ }^{1}$ Escola Paulista de Medicina da Unifesp, São Paulo, SP, Brasil ${ }^{2}$ Université de Paris VII - Denis Diderot; Universidade Federal de Minas Gerais (UFMG), Belo Horizonte, MG, Brasil
Endereço para correspondência:

Ethel Cukierkorn Battikha

Avenida Ministro Gabriel de Rezende Passos, 196, $1^{\circ}$ andar - Moema

CEP 04521-020 - São Paulo/SP

E-mail: ethelcbattikha@uol.com.br

Conflito de interesse: nada a declarar

Aprovado em: 10/7/2013 
ção do diagnóstico; situações de identificação com os pais; comunicação da morte e participação na entrevista.

Resultados: A interpretação das categorias propiciou a compreensão dos mecanismos psíquicos mobilizados nos médicos na relação com os pais dos bebês e expôs a angústia e o sofrimento suscitados nos residentes no atendimento assistencial e no processo de formação, para os quais estão desprovidos de ancoragens psíquicas.

Conclusões: A partir do conteúdo que se explicitou na análise das entrevistas, verificou-se a necessidade de uma proposta de intervenção na formação desses profissionais que favoreça a elaboração das experiências vividas no cotidiano da Unidade, a fim de propiciar uma saída menos angustiante e defensiva para o médico, inclusive na relação com o paciente e com os pais.

Palavras-chave: educação médica; internato e residência; neonatologia; psicanálise.

\section{RESUMEN}

Objetivo: Analizar e interpretar las repercusiones psicológicas suscitadas en el médico neonatologista en formación debido a la entrada y a la permanencia de los padres en la Unidad de Terapia Intensiva Neonatal.

Métodos: Estudio sustentado en la teoría psicoanalítica, manteniéndose una interlocución metodológica con la investigación cualitativa en salud. Veinte residentes en Neonatología, de cinco instituciones públicas de la provincia de São Paulo (Brasil), participaron de una entrevista semiestructurada individual. A partir de innúmeras lecturas del material, objetivando los núcleos de sentido emergentes, significativos para el objeto de investigación, se eligieron categorías para análisis e interpretación: permanencia de los padres en la Unidad de Terapia Intensiva Neonatal y su repercusión en la actuación del neonatologista; comunicación del diagnóstico y qué los padres deben saber; impases entre los médicos y los padres de los bebés en la comunicación del diagnóstico; situaciones de identificación con los padres; comunicación de la muerte y participación en la entrevista.

Resultados: La interpretación de las categorías propició la comprensión de los mecanismos psíquicos movilizados en los médicos en la relación con los padres de los bebés y expuso la angustia y el sufrimiento suscitados en los residentes en la atención asistencial y en el proceso de formación, para los que están desprovistos de anclajes psíquicos.

Conclusiones: A partir del contenido que se explicitó en el análisis de las entrevistas, se verificó la necesidad de una propuesta de intervención en la formación de esos profesionales que favorezca la elaboración de las experiencias vividas en el cotidiano de la Unidad, a fin de propiciar una salida menos angustiante y defensiva para el médico, incluso en la relación con el paciente y con los padres.

Palabras clave: educación médica; internato y residencia; neonatología; psicoanálisis.

\section{Introduction}

Many questions are raised by neonatologists regarding the presence of parents in the Neonatal Intensive Care Unit, whom, initially excluded ${ }^{(1)}$, went from restricted access to open access $^{(2)}$. It is important to research the meanings assigned by interviewees to these experiences, to support proposals for interventions in the education of the resident physician.

The performance of neonatologists has several singularities. In healthcare practice, they are faced with extreme situations linked to death and helplessness, mobilizing anguish that evoke primitive experiences inherent to the human subject ${ }^{(3)}$. They are exposed daily to the psychic pain of the parents, as well as their ambivalent and paradoxical reactions ${ }^{(4)}$. They can expect to receive recognition and get hatred and resentment, or even a full submission. They are objects of massive projections; i.e., they receive an intense emotional load from the parents, who can both expect and demand unlimited power from them, or identify them with their own feelings of powerlessness.

Residents are trained in the required skills to undertake interventions required in baby care ${ }^{(5)}$; however, they are faced with intersubjective issues that have implications in their professional practice. Therefore, it is essential to understand how they are affected by their work.

This study aimed to analyze and interpret the psychological repercussions of parental presence in the NICU on the neonatologist under training.

\section{Method}

Study based on qualitative research ${ }^{(6,7)}$, sustained in the psychoanalytic field ${ }^{(8)}$. From December 2007 to January 2008, 19 women and one man participated in the study, totaling 20 residents from five public institutions located in the state of São Paulo. The Neonatology Services from these institutions have a tradition of performing collaborative work with the discipline of Neonatal Pediatrics from Universidade Federal de São Paulo (Unifesp), justifying the choice to conduct the 
interviews. We chose not to interview residents attending the discipline of Neonatal Pediatrics at Escola Paulista de Medicina from Unifesp, as not to contaminate the results, given that the researcher has direct contact with them.

Lecturers who were heads of units of university hospitals were contacted and institutions were invited to participate; so, the project was referred to them. Residents were invited personally by the researcher, having been contextualized on the history and purpose of the research. The fact that there was no compulsory participation was reinforced; however, all residents expressed their desire to participate. The interviews were scheduled at each of the institutions, although there were some absences due to complications in the unit.

Residents were interviewed individually, in a rather reserved site at the institutions of origin, having been informed about the content of the term of free and informed consent, the preservation of the secrecy of their identities, the use of the recorder, besides being notified that the material would be worked as a whole and would not appear in full on the study.

The researcher conducted a semi-structured interview, near the end of the 1st year of residency, from a common roadmap of guiding topics ${ }^{(9,10)}$ : the permanence of parents in the Neonatal Intensive Care Unit and its repercussions on the performance of the neonatologist; the daily contact with parents in the Neonatal Intensive Care Unit; the communication of the diagnosis to parents/issues arising from this communication; knowledge about the history of the baby; situations of identification with parents; communicating the death of a child; themes from the roadmap and/or others covered during residency and in which way.

At the beginning of the interviews, the researcher proposed that the interviewees felt as free as possible to talk about what occurred to them, in the way they wished. The priority was listening to the singular form of speech articulation of the resident, leaving room for free association ${ }^{(11)}$ on the topics. The roadmap did not involve sequential order, given that from the proposal of a theme, others may emerge, even without suggestion by the researcher.

The material presented in the several interviews was worked together and, to do so, the content of analysis of Bardin ${ }^{(12)}$ was used as an instrumental resource: after repeated readings of the emerging material, the content of the various interviews is reduced into logic units, and the these parts are synthesized into categories of analysis.

The number of interviews was based on the criterion of saturation ${ }^{(13)}$ endorsed by qualitative research, which consists on the recognition by the field researcher that the research object was seized, from a determined number of interviews.
The project was approved by the Research Ethics Committees of the participating institutions and all residents signed the informed consent for voluntary participation in the study.

\section{Results}

Six categories of analysis were elected, which are presented with the respective fragments of speeches in italics, followed by the analysis and discussion. It is noteworthy that these may or may not coincide with the themes of the suggested roadmap to guide the interviews.

In this article, we present excerpts from the interviews, so that the reader can understand how this material was worked. Respondents were identified by an initial, randomly chosen, to preserve the secrecy of their identities.

The categories of analysis are as follows:

1) The permanence of parents in the neonatal Intensive Care Unit and their repercussion on the performance of the neonatologist. In this category of analysis, we looked at the ways the residents signify the presence of parents in the unit and how they are affected by it.

$\{\ldots\}$ There are the two sides of the presence of the parents in the ICU $\{. .$.$\} I think that, on the child's side, it is good \{...\} but for$ us, it is a bit complicated $\{\ldots\}$ because, often, they do not $\{\ldots\}$ have the notion that we cannot be available to them 24 hours; sometimes, you're taking care of another baby and they call you in the middle of the procedure $\{\ldots\}$ I think they should stay with the baby, but there should be a specific time when we give information and this time should be respected, you know \{...\}? They should know that the doctor has other things to do $\{\ldots\}$ many times they ask $\{\ldots\}$ "Why isn't the doctor here?" $\{\ldots\}$ I get mad $\{. .$.$\} I know the anguish they are going through, but,$ unfortunately, I don't take care of their child only, I have a lot of children to take care of $\{\ldots\}$ (P.)

On the one hand is good, that they understand better what is going on $\{\ldots\}$ But, on the other hand, there are many parents that disturb a lot. For instance, there are some who think you are only looking after their son \{...\} I feel bad, I feel mad, because they don't see our side. They only see their side $\{. .$.$\} they want$ exclusivity. "But my case is different" $\{\ldots\}(\mathrm{O}$.

$\{\ldots\}$ Then, well, if it were my son, I would like to be there by his side $\{\ldots\}$ On the other hand, it disrupts routines a lot, especially those very inquisitive mothers, who ask a lot, you know? \{...\} and well, this is kind of inevitable, because it is a risk situation, isn't it? And it is a serious situation, so, it is understandable that the mother is desperate $\{. .\}.(\mathrm{J}$. 
The residents recognize the importance of parents staying in the unit, but, on the other hand, this permanence disturbs, annoys, tests, and is experienced as an excessive and intrusive demand. Doctors go from identification with parents, putting themselves in their shoes, and at the same time, experience the resentment by not feeling that their efforts were recognized.

The demands to physicians - especially those that cannot be met - can be experienced by the professional as criticism and disregard. The excerpts from interviews allow to infer that parents project an unlimited power onto the doctors, requiring a knowledge and an unconditional and absolute availability, which certainly results from their own powerlessness in the face of their son. It is noticed that at this traumatic time, the pain and suffering prevent parents from allocating attention, either to the doctor, or to another baby and their parents. The demand for the establishment of rules, with organized schedules to talk with parents appears in the discourse of the interviewees, which can be understood as the expression of the need for a coordinator who can guide and control the relations, working as a tertiary mediator. The permanence of the parents in the unit was also mentioned in the interviews as a way of testimony, complicity, and legitimation of medical care to the baby, even when the results are different than desired.

2) Communicating the diagnosis: what parents should know? Faced with the issue of conveying the baby's diagnosis ${ }^{(14)}$, respondents revealed basically two different conceptions of what should be said to the parents. Let us look at the first one.

\{...\} When the baby comes into the ICU, I already say: "Look, your son is preterm, the chances of having an infection are very high, the chances of getting worse are bigh, there is a risk that he might have sequelae; he can improve, but for having stayed in the ICU, he may have injuries in the lungs, in the brain" (C.) Everything! $\{\ldots\}$ that he can bleed in the head, in the lungs, that this could happen, that can happen $\{. .$.$\} So, well, I think it is$ always good to leave parents prepared and aware of everything that can happen $\{\ldots\}$ (A.)

I think they should know all the risks that the baby is running, because if he suddenly dies, it is a way of leaving them somewhat prepared, and we are also protecting ourselves in this sense $\{. .$.$\} (S.)$

The explicit requirement of "saying everything", understood as announcing what is happening and what might happen for the baby's condition, was presented in many interviews as a diagnostic and even prognostic prediction. The analysis of the data available indicates that this anticipation is associated with the discharge of medical distress, which may, at any time, be surprised, and may experience what they cannot control, avoid, or predict as a failure and/or inability. Moreover, they seem to assume that the trust the parents deposit on them is based on a supposedly unconditional knowledge, as well as the belief that if parents know everything that may happen, this may protect them from suffering or at least mitigate it, if the announced is confirmed. However, the anticipation of a prognosis that is not confirmed by the evolution of the case, does not occur without consequences ${ }^{(1,15)}$. The suspicions that may fall on the baby's development, despite the nonconfirmation, can have a self-fulfilling effect, implying an anticipation of failure ${ }^{(16)}$.

In a contrasting way, there are residents who support nonexhaustive and non-predictive communication, so as not to burden parents with excessive information that cannot be processed $^{(17)}$, attempting to preserve a crack, an opening, to protect the imaginative capacity and investment of parents in their child. This can be seen in the following excerpt.

$\{$...\}To inform parents about the chances that he baby has, without saying anything about the future, because, in Neonatology, it is a box of surprises \{...\} I think that everything that we say at this moment is going to be $\{\ldots\}$ a stamp $\{\ldots\}$ so, if we say more, certainly the baby will already be with a closed diagnosis for the mother $\{. .\}.(\mathrm{H}$.

3) Impasses between doctors and parents in the communication of the diagnosis:

$\{$...\}Sometimes, we come to the mothers, to talk about the gravity of the problem, that we might not be able to save them, or that they might remain with an important sequela. Next, they ask: "But how much is he weighing?" $\{\ldots\}$ it is, actually, for us, a great frustration, no to be able to meet what that mother was hoping for, her expectations $\{\ldots\}$ (I.)

$\{\ldots\}$ She even asked about the little dribble in the mouth; we said: "Ob my God! So many important things and she asks about the drool in her mouth \{...\}" (J.)

Respondents reported that, often, after reporting a diagnosis or a severe prognosis, the mother asks how much weight the baby gained. Another recurring issue is the difficulty of parents to understand the diagnostic communication ${ }^{(18)}$ and the need to repeat the same information over and over again, as if for 
the first time, which can cause both discomfort and irritation to the doctor. Faced with the impasse between what they want the parents to listen and understand and the questions that return and insist, despite all the explanation offered, resident physicians seek to understand what is implied in this difficulty. Their interpretations fall within the type of language used ${ }^{(19)}$ and the socioeconomic and cultural level of the parents, oscillating among these factors defensive denial and maintenance of hope and the loving investment of parents in their baby ${ }^{(20)}$. For parents, it is distressing to hear the diagnosis. It seems that it is also excessive and distressing for the doctor to be faced with the limits of Medicine, and of their own performance at every question submitted to them, remembering repeatedly what they cannot repair and/or avoid.

4) Situations of identifications with parents:

$\{. .$.$\} You have a son, just the same, and you want him to grow,$ to run, to play, and to study \{...\} right?! (C.)

I want a cesarean with a buge curt out for he baby, because we see so many asphyxic babies, not due to a wrong cut, nothing like that, but because it was hard to leave; there are those babies convulsing, and babies intubated, and babies $\{\ldots\}$ It distresses me, you know? (M.)

$\{\ldots\}$ And, usually, we always say, are those prenatal cares with nine consultations, the little baby with 39 weeks, good weight, beautiful baby, first son, which generates all the expectations in the world in that child, and the child dies (H.)

The data analysis showed that the presence of parents in the Unit intensified the identifications of the doctors with the parents. Although the roles occupied are marked by a difference between the one who offers help and those who need that their child is the subject of this care, there is a symmetry that is invariably revealed. Doctors put themselves in the shoes of parents regarding their own experience with the death of a loved one by recognizing their own weakness in the face of lack of control over illness and death, or a future desire for a son, as well as the fear of having a child that is born with problems. The distressing identification with the mothers of babies referred to as "good", at term, big, beautiful, but who had problems during delivery, was recurrent. When faced with desired babies, whose mothers had a careful prenatal, the residents feel more identified with the situation, since it is how they imagine themselves facing a future pregnancy, planned and well cared, with a future desired child and at term.
The death of these "good" babies or the sequelae arising from these births have the effect of traumatic shock ${ }^{(17)}$, since they happen unexpectedly and, therefore, disorganize the references referring to the frailty and the imponderable that we all are equally subject to. These identifications may provide empathy and an emotional bond with the parents, but are also threatening to the doctor and, therefore, mobilize defenses.

5) Communicating death:

Failure is when the baby dies, right? \{...\} (U.)

I think this is the worst part of the job. We $\{\ldots\}$ because it is not the kind of news that we can give by half. (D.)

That is not what we work for (I.)

When you pick those patients that you don't see prognosis $\{\ldots\}$ I feel a little incapable, a little unable, a little "Isn't there anything else that I could do really, that perhaps I'm not knowing bow to do it?" (O.)

It not easy to be the bearer of the news that is irreparable, that has no happy ending, revealing the fall of the healing ideal $^{(21,22)}$. When it is possible to save, the doctor may come to feel as a winner and, in this sense, his actions would confirm his effectiveness. In contrast, when confronted with the limits and the insurmountable, he may also feel looser, helpless, and guilty. The doctor can deposit in medicine and in his performance an imaginary of completeness ${ }^{(23)}$, and may experience the limits as a blow to his self-esteem, triggering anguish and suffering ${ }^{(24)}$. It is someone else's death, but it evokes the finitude of all of us, as well as other limits, impossibilities, and losses. These experiences can be invasive and excessive to the doctor, which is why often quickly communicating a bad diagnosis or death is a defensive resource to release anxiety. In the interviews, it is recognized a request for an opportunity to speak about this anguish, which is, so many times, tolerated in silence.

6) Participation in the interview - helplessness and ideals: I'm feeling the need to talk about it $\{\ldots\}$ looking at my feelings, and that perhaps if I weren't talking to anyone I wouldn't focus on $\{\ldots\}$ Willing to do better $\{\ldots\}$ to talk to that mother in a way that I'm not going to give her attention at the moment, but, I'll leave her with the assurance that someone cares about her problem. (J.)

It was offered an opportunity for the doctors to be listened to, and they were receptive to the possibility of being heard by someone outside their habitual relations, uncritically, and with little direction ${ }^{(18)}$. The interest in listening to them was qualified as recognition and investment in them. 


\section{Discussion}

The resident doctor — faced with so many demands from parents of babies, professors, and those generated by their own expectations - needs, in his training, an investment that may transform the psychic excesses in statements and possible elaborations.

The stress that he they are submitted to during the process of learning and practice, as well as in the relationship with patients, has been a focus of interest, with proposals of interventions ${ }^{(25-27)}$. According to the interpretation of the data from the interviews, part of this stress has a close relationship with excessive anxieties that are raised, which once unnamed, cannot produce psychic work. Repetition and the time of experience are not transformers themselves. What can be transformative and offer new possibilities and anchors for this praxis is reflection.

The interviews had an academic purpose. However, they revealed having provided to the residents an employment, even if incipient, of psychic connection. It is concluded that this study confirmed the elaborative and organizer value of

\section{References}

1. Klaus M, Kennell J. Pais/Bebê: a formação do apego. Porto Alegre: Artes Médicas; 1992.

2. Brasil - Presidência da República. Lei n 8.069, de 13 de julho de 1990. Dispõe sobre o Estatuto da Criança e do Adolescente e dá outras providências. Brasília: Diário Oficial, 1990.

3. Nogueira-Martins LA. Residência médica: estresse e crescimento. São Paulo: Casa do Psicólogo; 2005.

4. Druon C. Ajuda ao bebê e aos seus pais em terapia intensiva neonatal. In: Wanderley DB, editor. Agora eu era o rei: os entraves da prematuridade. Salvador: Ágalma; 1999. p. 35-54.

5. Sociedade Brasileira de Pediatria [homepage on the Internet]. Programa de residência médica - Área de atuação Neonatologia [cited 2010 May 01]. Available from: http://www.sbp.com.br/pdfs/Programa_de_Residencia_ Medica_NeonatologiaOK.pdf

6. Demo P. Metodologia do conhecimento científico. São Paulo: Atlas; 2000.

7. Minerbo M. Estratégias de investigação em psicanálise: desconstrução e reconstrução do conhecimento. São Paulo: Casa do Psicólogo; 2000.

8. Mezan R. Que significa "pesquisa” em psicanálise? In: Silva M, editor. Investigação e psicanálise. Campinas: Papirus; 1993. p. 49-89.

9. Mannoni M. A primeira entrevista em psicanálise. Rio de Janeiro: Campus; 1993.

10. Triviños AN. Introdução à pesquisa em ciências sociais. São Paulo: Atlas; 1987.

11. Laplanche J, Pontalis JB. Vocabulário da psicanálise. São Paulo: Martins Fontes; 1983.

12. Bardin L. Análise de conteúdo. Lisboa: Edições 70; 1979.

13. Minayo MC. O desafio do conhecimento: pesquisa qualitativa em saúde. São Paulo: Hucitec; 2006.

14. Conselho Federal de Medicina [homepage on the Internet]. Código de ética médica. Brasília: CFM, 2010 [cited 2013 Jul 30]. Available from: http://www. cremers.org.br/pdf/codigodeetica/codigo_etica.pdf an opportunity for the residents to be listened to, appearing as a key indicator for an intervention proposal in the training these professionals. The specificity of this proposal intends to work the contents revealed in the analysis of the interviews, so that actions can be taken in this critical time of training, favoring the metabolism of experiences and enabling a less distressing and defensive way out for the doctor, including the relationship with the patient and his parents.

\section{Acknowledgements}

To the institutions School of Medical Sciences from Santa Casa de São Paulo, School of Medical Sciences of Botucatu from Universidade Estadual Paulista "Júlio de Mesquita Filho" (Unesp), School of Medical Sciences of Ribeirão Preto from Universidade de São Paulo (USP), School of Medical Sciences from Universidade Estadual de Campinas (Unicamp), Hospital Municipal e Maternidade Escola Dr. Mário de Moraes Altenfelder Silva and Maternidade Escola de Vila Nova Cachoeirinha, on behalf of their faculty members, who enabled the completion of this work.

15. Cabassu G. Palavras em torno do berço. In: Wanderley DB, editor. Palavras em torno do berço. Salvador: Ágalma; 1997. p. 21-32.

16. Jerusalinsky J. Quando o que se antecipa é o fracasso: prevenção secundária e estimulação precoce. In: Camarotti MC, editor. Atendimento ao bebê: uma abordagem interdisciplinar. São Paulo: Casa do Psicólogo; 2001. p. 35-42.

17. Bleichmar S. Clínica psicanalítica e neogênese. São Paulo: Annablume; 2005

18. Battikha EC, Faria MC, Kopelman BI. The maternal representations about a baby who is born with serious organic diseases. Psic Teor e Pesq 2007; 23:17-24.

19. Burlá C, Py L. Peculiaridades da comunicação ao fim da vida de pacientes idosos. Rev Bioet 2005;13:97-106.

20. Dommergues JP, Bader-Meunier B, Epelbaum C. A comunicação do diagnóstico na doença crônica da criança. In: Leitgel-Gille M, editor. Boi da cara preta. Salvador: Ágalma; 2003. p. 121-42.

21. Rocco RP. Relação estudante de medicina-paciente. In: Mello-Filho J, editor Psicossomática hoje. Porto Alegre: Artes Médicas; 1992. p. 45-56.

22. Díaz FG. Breaking bad news in medicine: strategies that turn necessity into a virtue. Med Intensiva 2006;30:452-9.

23. Freud S. Sobre o narcisismo: uma introdução. In: Freud S, editor. Edição standard brasileira das obras psicológicas completas. Rio de Janeiro: Imago; 1976.

24. Zaidhaft S. Morte e formação médica. Rio de Janeiro: Francisco Alves; 1990

25. Freudenberger HJ. The staff burn-out syndrome in alternative institutions. Psychother Theory Res Pract 1975;12:73-82.

26. Alexander D, Monk JS, Jonas AP. Occupational stress, personal strain, and coping among residents and faculty members. J Med Educ 1985;60:830-9.

27. Butterfield PS. The stress of residency. A review of the literature. Arch Intern Med 1988;148:1428-35. 